Gut, 1989, 30, 90-96

\title{
Beneficial effect of 8-ornithin vasopressin on renal dysfunction in decompensated cirrhosis
}

\author{
K LENZ, H HÖRTNAGL, W DRUML, G GRIMM, A LAGGNER, \\ B SCHNEEWEISZ, AND G KLEINBERGER
}

From the 1st Department of Internal Medicine and Institute of Biochemical Pharmacology, University of Vienna, A-1090 Vienna, Austria

SUMMARY In nine patients with decompensated alcoholic cirrhosis of the liver and impaired renal function the effect of 8-ornithin vasopressin (ornipressin) on renal function and haemodynamic parameters was studied. Ornipressin was infused at a dose of $6 \mathrm{IU} / \mathrm{h}$ over a period of four hours. During ornipressin infusion an improvement of renal function was achieved as indicated by an increase of creatinine clearance $(76(15) \% ; p<0.01)$, urine volume $(108(29) \% ; p<0.05)$ and sodium excretion (168 (30)\%; $<<0.05)$. The hyperdynamic circulation of hepatic failure, as characterised by increased cardiac index and heart rate as well as decreased systemic vascular resistance was reversed to a nearly normal circulatory state during ornipressin infusion. The raised noradrenaline plasma concentration $(1.74(0.31) \mathrm{ng} / \mathrm{ml})$ and plasma renin activity $(13.5(3.9) \mathrm{ng} / \mathrm{ml} / \mathrm{h})$ were lowered during ornipressin infusion to $0.87(0.21) \mathrm{ng} / \mathrm{ml}$ and $5.9(2.1) \mathrm{ng} / \mathrm{ml} / \mathrm{h}$, respectively $(\mathrm{p}<0.01)$. The efficacy of a vasoconstrictor agent in reverting a hyperdynamic state and improving renal function provides evidence for the substantial role of accumulation of vasodilator substances and subsequent activation of sympathetic nervous system and renin-angiotensin-axis in the pathogenesis of renal dysfunction in hepatic failure. Values are expressed as mean (SE).

Progressive impairment in renal water and sodium excretion frequently develops in patients with advanced hepatic disease and is associated with a poor prognosis. ${ }^{1-3}$ The pathogenetic mechanisms involved in the renal dysfunction are not completely elucidated and consequently, therapeutic approaches are rather limited.

Several pathogenetic mechanisms have been suggested. The absence of morphological abnormalities of the kidney' and the successful transplantation of kidneys from cirrhotic patients dying in oliguric renal failure ${ }^{4}$ point to a functional impairment rather than tissue damage. Volume as well as non-volume factors have been discussed. A decrease in effective arterial blood volume has been suggested as one of the factors responsible for renal sodium and water retention especially in patients with decompensated

Address for correspondence: Kurt Lenz, MD, 1st Department of Internal Medicine, Lazarettgasse 14, A-1090 Vienna, Austria.

Received for publication 14 July 1988. cirrhosis and ascites. ${ }^{5}$ In support of this, renal function improves during plasma expansion, induced either by infusion of plasma expanders ${ }^{6}$ or by headout water immersion, ${ }^{78}$ at least in a subgroup of patients. As non-volume dependent factors the increased activity of the sympathetic nervous system $^{2-14}$ as well as the renin-angiotensin-system, ${ }^{15-18}$ impaired renal production of kallikrein and prostaglandins, ${ }^{19} 20$ diminished function of atrial natriuretic peptide $^{21-23}$ have been suggested to contribute to the renal dysfunction. None of these proposed mechanisms, however, sufficiently explains the pathogenesis of this complication. Likewise, the therapeutic regimen deduced from these pathogenetic conceptions have been of limited efficacy.

We recently observed an increase of urine volume, sodium excretion and creatinine clearance during constant, low dose infusion of the vasopressin analogue 8-ornithin vasopressin (ornipressin) in a patient with decompensated cirrhosis. ${ }^{24}$ As compared with vasopressin, ornipressin is equipotent as a 
vascoconstrictor agent, whereas its antidiuretic potency is reduced to about $20 \%{ }^{25}$ In the present investigation the beneficial effect of ornipressin on renal function was further evaluated in a larger number of patients with decompensated cirrhosis. Despite the obvious paradox of using a vasoconstrictor agent in a state of increased renal vascular tone, ornipressin infusion resulted in a pronounced improvement of renal function.

\section{Methods}

\section{PATIENTS}

Nine patients with decompensated alcoholic cirrhosis of the liver, who were admitted to the intensive care unit, because of deteriorating renal function despite volume expansion (central venous pressure $>6$ $\mathrm{mmHg}$ ) and/or hepatic encephalopathy, entered the study. The mean age of these patients (three women, six men) was 50 years (38-62 years). All patients had impaired liver function: serum cholinesterase $<1.0$ $\mathrm{U} / 1$ (normal range 2.2-3.8 U/l), prothrombin $\left(\right.$ Normo-Test ${ }^{\mathrm{R}}$ ) ratio $<0.45$ (of normal), bilirubin $>1.8 \mathrm{mg} / 100 \mathrm{ml}$ and albumin $<2.9 \mathrm{~g} / \mathrm{l}$. All patients had ascites. Renal function was impaired in seven patients (creatinine clearance $<45 \mathrm{ml} / \mathrm{min} / 1.73 \mathrm{~m}^{2}$ body surface area; BSA). The remaining two patients had a creatinine clearance above $75 \mathrm{ml} / \mathrm{min} / 1.73 \mathrm{~m}^{2}$ BSA. The fractional elimination of sodium was below $1 \%$ in all nine patients before the study. All patients received spironolactone ( $100 \mathrm{mg}$ twice daily) for more than four weeks before admission to hospital. After admission to hospital the dose was increased to $200 \mathrm{mg}$ (twice daily, iv, at least five days before study) and maintained during the day of the study. None of the patients received any additional diuretic therapy at least five days before the study. Six patients improved during intensive care, three of the patients deteriorated and finally died in coma. Liver damage was confirmed by biopsy or necropsy in all patients.

\section{PROTOCOL OF THE STUDY}

The study was started at 800 am at least 24 hours after admission of the patient to the intensive care unit. After a two hour preperiod ornipressin (POR 8, Sandoz, Switzerland) was continuously infused at a dose of $6 \mathrm{IU} / \mathrm{h}$ through a central venous catheter over a period of four hours, using an infusion pump (Perfusor, Braun Melsungen, FRG). This was followed by a postperiod of two hours. During the study parenteral nutrition adapted for liver failure was continued (infusion rate: $1 \mathrm{ml} / \mathrm{min} / \mathrm{kg} ; 30 \mathrm{mmol}$ sodium/l).

The study was carried out according to the principles of the declaration of Helsinki, and informed consent was obtained in each case. The consent form had been reviewed and approved by the Ethical Committee of the University of Vienna. If the patient was unable to understand the nature of the procedures, the family members were specifically informed.

\section{CLINICAL TESTS}

Haemodynamic monitoring was carried out using a femoral artery catheter and a percutaneously inserted $7 \mathrm{~F}$ flow directed thermodilution pulmonary artery catheter (Gould SP 5507). Cardiac output was estimated by the thermodilution technique with $10 \mathrm{ml}$ $5 \%$ solution of dextrose in water at $0^{\circ} \mathrm{C}$ (Gould Cardiac Output Computer). All measurements were done in triplicate, averaged, and expressed per $\mathrm{m}^{2}$ BSA. The intravascular pressures were calibrated against a mercury sphygmomanometer and were recorded by a Hewlett-Packard transducer 1290 A (with the midaxillary line as zero reference) and a Hewlett-Packard multichannel recorder. The values were averaged at the end of exspiration for three successive respiratory cycles. Mean pressures were derived by electronic integration. Systemic vascular resistance was calculated from standard formula. ${ }^{26}$ Haemodynamic data were recorded two hours, one hour, and just before the infusion of ornipressin, one, two, and four hours after the start of the infusion and one and two hours after the end of infusion.

The thermodilution catheter was also used for collecting mixed venous blood samples for blood gas analysis and oxymetry. Blood samples (arterial and mixed venous) were collected in two hour intervals. Blood gas analysis and oxymetry were done using IL 1303 and IL Co-oxymeter 282 (Instrumentation Laboratory, USA). Oxygen consumption and oxygen transport were calculated with standard formulae.

Urine was collected through a transurethral catheter in two hour periods for measurement of urine osmolality, sodium, and creatinine concentration. Serum osmolality, sodium and creatinine concentrations were measured before starting and at the end of ornipressin infusion. The concentrations of creatinine and sodium were determined by standard photometric methods (ACA DuPont, USA). The osmolality was measured by the freezing point method (Knauer osmometer, FRG). Creatinine clearance, free water clearance and fractionated elimination of sodium were calculated using standard formulas. ${ }^{27}$ Clearance values are expressed per $1.73 \mathrm{~m}^{2}$ BAS.

BIOCHEMICAL ANALYSES

For analysis of the plasma concentration of noradrenaline and plasma renin activity blood 
Table 1 Cardiovascular changes during ornipressin infusion (6IU/h) in nine patients with decompensated cirrhosis

\begin{tabular}{|c|c|c|c|c|c|c|c|c|c|}
\hline & & \multicolumn{2}{|l|}{ Preperiod } & \multicolumn{4}{|c|}{ Ornipressin infusion } & \multicolumn{2}{|c|}{ Postperiod } \\
\hline & & -2 & -1 & 0 & 1 & 2 & 4 & 5 & $6 h$ \\
\hline Heart rate (beats/min) & [78(4)] & $105(6)$ & $104(5)$ & $98(5)$ & $80(5)^{*}$ & $75(4)^{*}$ & $76(4)^{*}$ & $97(7)$ & $91(2)$ \\
\hline Mean arterial pressure $(\mathrm{mmHg})$ & {$[91(3)]$} & $80(6)$ & $82(5)$ & $80(5)$ & $104(5)^{*}$ & $99(5)^{*}$ & $95(5)^{*}$ & $76(5)$ & $80(8)$ \\
\hline Cardiac index $\left(1 / \mathrm{min} / \mathrm{m}^{2}\right)$ & {$[3 \cdot 5(0 \cdot 16)]$} & $5 \cdot 7(0.7)$ & $5 \cdot 8(0 \cdot 7)$ & $5 \cdot 4(0 \cdot 5)$ & $4 \cdot 4(0 \cdot 3)^{*}$ & $4 \cdot 1(0 \cdot 4)^{*}$ & $4.0(0.4)^{*}$ & $5 \cdot 1(0 \cdot 5)$ & $5 \cdot 7(0 \cdot 7)$ \\
\hline $\begin{array}{l}\text { Systemic vascular resistance } \\
\left(\mathrm{dyn} / \mathrm{sec} / \mathrm{cm}^{-5}\right)\end{array}$ & {$[1130(40)]$} & $546(49)$ & $575(56)$ & $585(44)$ & $918(70)^{*}$ & $854(118)^{*}$ & $950(89)^{*}$ & $632(95)$ & $570(69)$ \\
\hline $\begin{array}{l}\text { Pulmonary capillary wedge pressure } \\
(\mathrm{mmHg})\end{array}$ & {$[12(1)]$} & $12(2)$ & $12(1)$ & $11(1)$ & $13(2)$ & $14(2)$ & $13(2)$ & $11(2)$ & $9(1)$ \\
\hline
\end{tabular}

In square brackets control values taken from Barratt-Boyes and Wood $^{49}$ are indicated.

${ }^{*} \mathrm{p}<0.001 v$ preperiod values (Tukey's Studentised range test).

Data are expressed as mean (SE).

samples were collected just before the start of ornipressin infusion and two hours later into precooled heparinised tubes (for noradrenaline) and precooled tubes coated with sodium EDTA (for plasma renin activity). Plasma was separated by centrifugation at $+2^{\circ} \mathrm{C}$ and stored at $-20^{\circ} \mathrm{C}$ until estimation. Plasma noradrenaline concentrations and plasma renin activity were determined by a radioenzymatic method ${ }^{28}$ or a radioimmuno-assay, ${ }^{29}$ respectively. Plasma lactate concentration was determined just before the start and at the end of the ornipressin infusion with an enzymatic method (ACA DuPont, USA).

\section{STATISTICAL ANALYSIS}

Data are expressed as mean values (SE). Statistical analyses were carried out by means of the paired Student's $t$ test and Tukey's Studentised range test. A significance level of $p<0.05$ was chosen.

\section{Results}

The effect of ornipressin on haemodynamic parameters is summarised in Table 1. Before the onset of ornipressin infusion a hyperdynamic circulatory state, characteristic for liver failure, ${ }^{30-32}$ with increased cardiac index and heart rate and decreased systemic vascular resistance and mean arterial pressure was observed. During ornipressin infusion the hypercirculatory state was reversed to an almost normal circulation. A pronounced reduction in the raised cardiac index and heart rate and a considerable increase in the lowered systemic vascular resistance and mean arterial pressure were achieved. The cardiovascular improvement persisted only as long as ornipressin was infused.

The improvement of renal function during ornipressin infusion is outlined in Figure 1 and Table 2. In the seven patients with diminished glomerular filtration rate a significant increase of urine volume (from

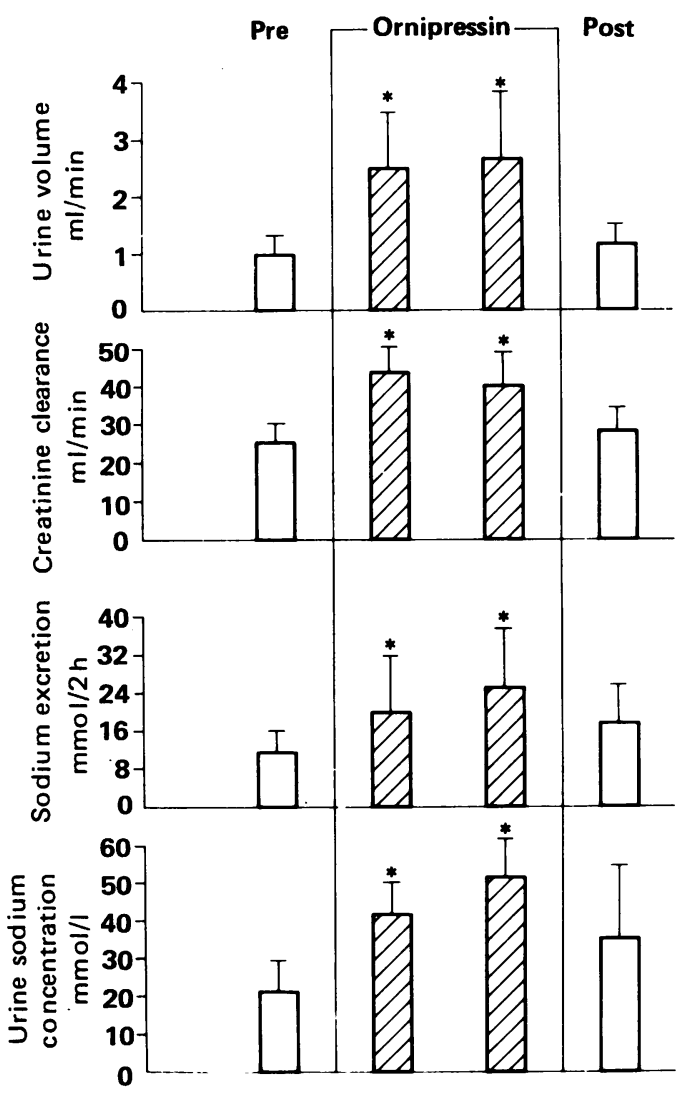

Fig. 1 Effect of ornipressin infusion (6 IU/h for four hours) on renal function in seven patients with decompensated cirrhosis and reduced creatinine clearance. The renal parameters were measured from urine samples collected within two hours. ${ }^{*} p<0.05 \mathrm{v}$ preperiod values (paired Student's $t$ test). The serum concentrations of electrolytes, urea and creatinine in the preperiod were the following: $K^{+}$: 4.4 (0.4) mmolll; $\mathrm{Na}^{+}: 133$ (2) mmolll; BUN: 51 (9) $\mathrm{mg} / 100$ $\mathrm{ml}$; creatinine: $2 \cdot 8(0 \cdot 4) \mathrm{mg} / 100 \mathrm{ml}$. 
Table 2 Effect of ornipressin on renal function in two cirrhotic patients with normal glomerular filtration rate

\begin{tabular}{lcccc}
\hline & Preperiod & Ornipressin & Postperiod \\
\hline Creatinine clearance & 138 & 245 & 195 & 97 \\
(ml/min/1·73 m BSA) $^{2}$ & 89 & 132 & 102 & 92 \\
Urine volume & $1 \cdot 4$ & $2 \cdot 0$ & $2 \cdot 9$ & $1 \cdot 7$ \\
(ml/min) & $1 \cdot 3$ & $2 \cdot 7$ & $2 \cdot 2$ & $1 \cdot 8$ \\
Sodium excretion & 15 & 24 & 51 & 28 \\
(mmol/2 h) & 2 & 5 & 6 & 3 \\
Urine sodium concentration & 87 & 100 & 146 & 142 \\
(mmol/) & 7 & 17 & 23 & 13 \\
\hline
\end{tabular}

Serum concentrations of electrolytes, urea and creatinine during the preperiod: $\mathrm{K}^{+}: 3$ and $3.1 \mathrm{mmol} / \mathrm{l} ; \mathrm{Na}^{+}$: 143 and $142 \mathrm{mmol} / \mathrm{BUN}$ : 2 and $16 \mathrm{mg} / 100 \mathrm{ml}$; creatinine: 0.6 and $1.6 \mathrm{mg} / 100 \mathrm{ml}$, respectively.

$1.0(0 \cdot 3)$ to $2.6(1) \mathrm{ml} / \mathrm{min})$, creatinine clearance (from $26(5)$ to $43(8) \mathrm{ml} / \mathrm{min} 1.73 \mathrm{~m}^{2} \mathrm{BSA}$ ), urine sodium excretion (from $10.7(7.0)$ to $21.6(14.7)$ $\mathrm{mmol} / 2 \mathrm{~h}$ ) and urine sodium concentration (from 22 (8) to $41(10) \mathrm{mmol} / \mathrm{l}$ ) in the first two hours of infusion. These values remained raised throughout the infusion period (Fig. 1). Even in the patient with the lowest creatinine clearance $(6.5 \mathrm{ml} / \mathrm{min})$ an improvement to $15 \mathrm{ml} / \mathrm{min}$ was achieved during ornipressin infusion. After cessation of the infusion the renal parameters returned to preinfusion values. A similar increase in renal function was also achieved in the two patients with a normal creatinine clearance (Table 2). In all nine patients free water clearance decreased during ornipressin infusion from $-16(9)$ $\mathrm{ml} / \mathrm{h}$ to $-40(13) \mathrm{ml} / \mathrm{h}(\mathrm{p}<0 \cdot 01)$. The fractional elimination of sodium increased from $0.66(0.12)$ to $1.1(0.5) \%(p<0.01)$. The observed increase in sodium excretion in response to ornipressin was independent from the initial amount of sodium excreted. A three to four-fold increase in sodium excretion was achieved during ornipressin infusion even in three of the patients in whom sodium excretion was diminished to the low rate of about 10 $\mathrm{mmol} / 24 \mathrm{~h}(0.4-1.0 \mathrm{mmol} / 2 \mathrm{~h})$.

The plasma concentration of noradrenaline was initially raised $(1.74(0.31) \mathrm{ng} / \mathrm{ml})$ and decreased to $0.87(0.21) \mathrm{ng} / \mathrm{ml}$ during ornipressin administration. The plasma renin activity declined from the initially high value of $13.5(3.9)$ to $5.9(2.1) \mathrm{ng} / \mathrm{ml} / \mathrm{h}$. The values of noradrenaline and plasma renin activity measured in the presence of ornipressin were, however, still above the normal concentrations (Fig. 2).

No major side effects were observed during ornipressin infusion. All patients responded with an increased bowel activity without abdominal cramps. Facial pallor was evident in two patients. In the electrocardiogram recorded throughout the ornipressin infusion, ST abnormalities were not detected.
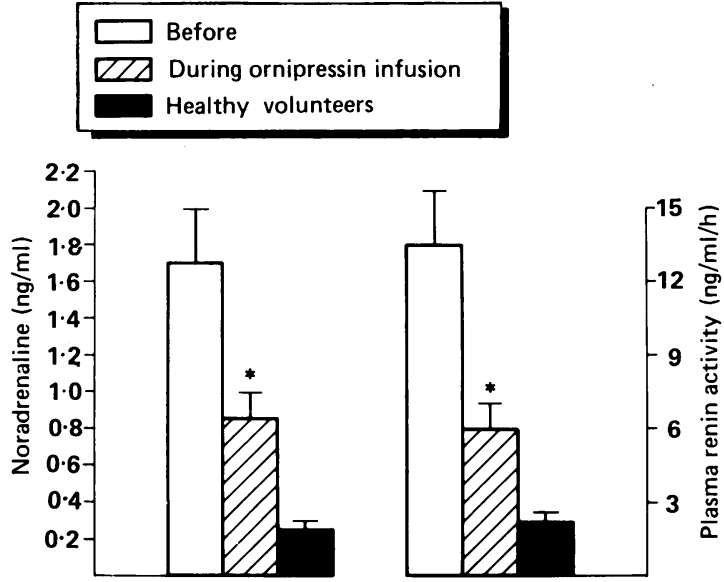

Fig. 2 Influence of ornipressin on the plasma concentration of noradrenaline $(n=5)$ and plasma renin activity $(n=6)$. The closed columns represent the control values measured in our experimental conditions. ${ }^{*} p<0.01 \mathrm{v}$ preinfusion levels (paired Student's t test).

Ornipressin did not affect the pulmonary capillary wedge pressure (Table 1). Although oxygen transport decreased during ornipressin infusion from 728 (77) to $479(45) \mathrm{ml} / \mathrm{min} / \mathrm{m}^{2}$ as a consequence of the decreased cardiac output, the oxygen consumption did not decrease (124 (8) before and $132(10) \mathrm{ml} / \mathrm{min} /$ $\mathrm{m}^{2}$ during ornipressin). As plasma lactate concentration did not change $(1.7(0.3)$ before and $1.5(0.3)$ $\mathrm{mmol} / \mathrm{l}$ during ornipressin) activation of anaerobic metabolism seems unlikely.

\section{Discussion}

Progressive renal impairment in advanced hepatic disease is characterised by sodium retention and a decrease in renal blood flow and glomerular filtration rate..$^{1-3}$ Intimately linked to hepatic failure is also a hyperdynamic circulatory state caused by a profound decrease in peripheral vascular resistance. ${ }^{30-32}$ As a baroreceptor mediated response to systemic circulatory alterations the activity of the sympathetic nervous system increases. ${ }^{10-12} 33$ In addition, the renin angiotensin system is activated. ${ }^{15-18}$ In the present study we have shown that during infusion of ornipressin in patients with decompensated cirrhosis the above mentioned characteristic changes were attenuated. A considerable improvement in renal function was achieved, as documented by an increase of creatinine clearance, urine volume output, and sodium excretion. The hyperdynamic circulation reverted to a nearly normal haemodynamic state. The increase in the activity of the sympathetic nervous system and renin angiotensin system was 
suppressed. This uniform effect of ornipressin provides evidence for a closely interrelated pathogenesis of these various organ system dysfunctions in advanced hepatic disease.

Several mechanisms might be involved in the improvement of renal function during ornipressin infusion. Normalisation of mean arterial pressure and/or redistribution of blood flow to the kidneys by ornipressin might result in an increase of renal blood flow by an increase in perfusion pressure and by this enhance renal function. In addition, the decrease in the initially high sympathetic activity during ornipressin infusion induced by the normalisation of blood pressure might have contributed to the efficacy of ornipressin. Increased sympathetic tone is probably involved in natrium and water retention by action at the tubular level $\mathrm{l}^{34-36}$ as well as by a reduction in renal blood flow caused by renal vasoconstriction. ${ }^{510^{1314}}$ The role of the sympathetic nervous system in the pathogenesis of impaired renal function in liver failure is further underlined by the recent observation that lumbal sympathetic blockade by local anaesthesia improved renal function in patients with decompensated cirrhosis. ${ }^{37}$ Increased sympathetic tone, however, cannot be solely responsible for the decrease in renal blood flow, because blockade of renal alpha-adrenoceptors by phentolamine infusion directly into the renal artery did not alter renal haemodynamics in cirrhotic patients ${ }^{3}$ and sympathetic block was only effective in cirrhotic patients with basal glomerular filtration rate below $25 \mathrm{ml} /$ $\min \cdot{ }^{37}$ In this respect it is noteworthy that ornipressin improved renal function even in cirrhotic patients with normal glomerular filtration rate. Furthermore infusion of noradrenaline considerably potentiates the beneficial effect of head-out water immersion on renal function. ${ }^{38}$ The observed decrease in plasma renin activity does not seem to play an important role in the improvement of renal function, as treatment with angiotensin receptor antagonists or angiotensin converting enzyme inhibitors does not ameliorate renal function in patients with hepatorenal syndrome. ${ }^{39}$ In addition, as in our patients, aldosterone antagonists are not effective anymore in this advanced disease state. Other pathogenetic factors discussed in connection with hepatorenal syndrome, such as decrease in the effective arterial blood volume $^{838}$ or an increase in intrahepatic pressure ${ }^{4041}$ might have been affected by ornipressin. All these mechanisms, however, are not sufficient to explain the therapeutic efficacy of ornipressin.

We are still confronted with the complex clinical entity of the hepatorenal syndrome. Profound vasodilation in the systemic circulation, possibly mediated by accumulation of vasodilator substances, such as substance $P,{ }^{12}$ is contrasted by vasoconstric- tion in the renal vasculature. ${ }^{3}$ The renal haemodynamic alteration, however, seems to be more complex, as, likewise, postglomerular vasodilation and possible opening of renal shunts have been postulated ${ }^{42}{ }^{43}$ Although the kidney has the ability to autoregulate renal blood flow in response to changes in arterial perfusion pressure, the mechanism of autoregulation may be disturbed in the presence of a vasodilating substance. Deen et $\mathrm{l}^{44}$ have shown in the rat that during vasodilation induced by administration of the potent smooth muscle relaxant, papaverine, the autoregulatory response of afferent and efferent arteriolar resistance to reduction in mean arterial pressure is essentially abolished. As an improvement of renal function in decompensated cirrhosis can be achieved by two contrasting means, namely either by the use of a vasoconstrictor agent such as ornipressin, octapressin ${ }^{456}$ and the alphasympathomimetic drug metaraminol ${ }^{43474}$ or by blockade of the sympathetic innervation of the kidney ${ }^{37}$ an imbalance between vasoconstrictor and vasodilator factors may play a causative role in the pathogenesis of hepatorenal syndrome. Further studies, however, are necessary to evaluate the effect of a vasoconstrictor agent on renal haemodynamics in order to obtain further insights into its mechanism of action and by this finally into the pathogenesis of hepatorenal syndrome.

On the basis of the present results we conclude that the use of vasoconstricting substances represents an effective tool in the treatment of renal failure in advanced hepatic disease. At the effective dose of ornipressin $(6 \mathrm{IU} / \mathrm{h})$ no major side effects were observed. Experience in a single patient indicates that the treatment with ornipressin can be continued for several days without development of side effects. ${ }^{24}$ During prolonged use of ornipressin, however, the possible development of cardiovascular complications cannot yet be definitely excluded. Further studies are necessary to support the proposed hypothesis and to evaluate the importance of this therapeutic approach in the long run.

We would like to thank $\mathrm{Mr} \mathrm{H}$ Reither for excellent technical assistance, Mrs W Krivanek for superb secretarial help and the nursing staff of the intensive care unit for helpful cooperation.

\section{References}

1 Papper S, Belsky JL, Bleifer KH. Renal failure in Laennec's cirrhosis of the liver. 1. Description of clinical and laboratory features. Ann Intern Med 1959; 51: 75973.

2 Shear L, Kleinerman J, Gabuzda J. Renal failure in patients with cirrhosis of the liver. I. Clinical and pathological characteristics. Am J Med 1965; 39: 184-98. 
3 Epstein M, Berk DP, Hollenberg NK, et al. Renal failure in the patient with cirrhosis. The role of active vasoconstriction. Am J Med 1970; 49: 175-85.

4 Koppel MH, Coburn JW, Mims MM, Goldstein H, Boyle JD, Rubini ME. Transplantation of cadaveric kidneys from patients with hepatorenal syndrome. N Engl J Med 1969; 280: 1367-71.

5 Better OS, Schrier RW. Disturbed volume homeostasis in patients with cirrhosis of the liver. Kidney Int 1983; 23: 303-11.

6 Tristani FE, Cohn JN. Systemic and renal haemodynamics in oliguric renal failure: effect of volume expansion. J Clin Invest 1967; 46: 1894-906.

7 Epstein M. Renal sodium handling in cirrhosis. In: Epstein M, ed. The kidney in liver disease. New York: Elsevier, 1983: 25-53.

8 Bichet DG, Groves BM, Schrier W. Mechanisms of improvement of water and sodium excretion by immersion in decompensated cirrhotic patients. Kidney Int 1983; 24: 788-94.

9 Hörtnagl H, Lochs $\mathrm{H}$, Kleinberger G, et al. Plasma catecholamines in hepatic coma and liver cirrhosis: role of octopamine. Klin Wochenschr 1981; 59: 1159-64.

10 Ring-Larsen H, Hesse B, Henriksen JH, Christensen NJ. Sympathetic nervous activity and renal and systemic haemodynamics in cirrhosis: Plasma norepinephrine concentration, hepatic extraction and renal release. Hepatology 1982; 2: 304-10.

11 Bichet DG, Van Putten VJ, Schrier RW. Potential role of increased sympathetic activity in impaired sodium and water excretion in cirrhosis. N Engl J Med 1982; 307: 1552-7.

12 Hörtnagl H, Singer EA, Lenz K, Kleinberger G, Lochs H. Substance $\mathbf{P}$ is markedly increased in plasma of patients with hepatic coma. Lancet 1984; i: 480-3.

13 Nicholls KM, Shapiro MD, Van Putten VJ, et al. Elevated plasma norepinephrine concentrations in decompensated cirrhosis. Association with increased secretion rates, normal clearance rates, and suppressibility by central blood volume expansion. Circ Res 1985; 56: 457-61.

14 DiBona GF. Renal neural activity in hepatorenal syndrome. Kidney Int 1984; 25: 841-53.

15 Wernze H, Spech HJ, Müller G. Studies on the activity of the renin-angiotensin-aldosterone system (RAAS) in patients with cirrhosis of the liver. Klin Wochenschr 1978; 56: 389-97.

16 Rosoff L, Williams J, Moult P, Williams H, Sherlock S. Renal haemodynamics and the renin-angiotensin system in cirrhosis. Relationship to sodium retention. Am J Dig Dis 1979; 24: 25-32.

17 Sellars L, Shore AC, Wilkinson R, James OFW, Robson V. Sodium status and the renin-angiotensinaldosterone system in compensated liver disease. Eur $J$ Clin Invest 1981; 11: 299-304.

18 Arroyo U, Planas R, Gaya J, et al. Sympathetic nervous activity, renin-angiotensin system and renal excretion of prostaglandin $\mathrm{E}_{2}$ in cirrhosis. Relationship to functional renal failure and sodium and water excretion. Eur J Clin Invest 1983 ; 13: 271-8.

19 Wong PY, Talamo RC, Williams GH. Kallikrein-kinin and renin-angiotensin systems in functional renal failure of cirrhosis of the liver. Gastroenterology 1977; 73: 1114-8.

20 Pérez-Ayuso RM, Arroyo V, Camps J, et al. Renal kallikrein excretion in cirrhotics with ascites: Relationship to renal haemodynamics. Hepatology 1984 ; 4: 24752.

21 Fernández-Cruz A, Marco J, Cuadrado LM, et al. Plasma levels of atrial natriuretic peptide in cirrhotic patients. Lancet 1985; ii: 1439-40.

22 Burghardt W, Wernze H, Diehl K-L. Atrial natriuretic peptide in hepatic cirrhosis: Relation to stage of disease, sympathoadrenal system and renin-aldosterone axis. Klin Wochenschr 1986; 64 [suppl VI): 103-7.

23 Arendt RM, Gerbes AL, Ritter D, Stangl E, Bach P, Zähringer $J$. Atrial natriuretic factor in plasma of patients with arterial hypertension, heart failure or cirrhosis of the liver. J Hypertens 1986; 4 [suppl 2: S131-5.

24 Lenz K, Druml W, Kleinberger G, et al. Enhancement of renal function with ornipressin in a patient with decompensated cirrhosis. Gut 1985; 26: 1385-6.

25 Berde B, Cerletti A. Medizinische und biologische Aspekte von pharmakologischen Arbeiten mit synthetischen Peptiden von neurohypophysärem Typus. Klin Wochenschr 1964; 42: 1159-65.

26 Barry WH, Grossmann W. Cardiac catheterization. In: Braunwald E, ed. Heart disease. Philadelphia: Saunders, 1980: 278-307.

27 Ganong WF. Review of Medical Physiology. Los Altos, California: Lange Medical Publications, 1983: 579.

28 Hörtnagl H, Magometschnigg D, Prager J. Hyperkinetic heart syndrome: The role of the sympathetic nervous system. Cardiology 1982; 69: 74-83.

29 Haber E, Koerner T, Page LB, Purnode A. Application of a radioimmunoassay for angiotensin I to the physiologic measurements of plasma renin activity in normal human subjects. J Clin Endocrinol Metabol 1969; 29: 1349-55.

30 Murray JF, Dawson AM, Sherlock S. Circulatory changes in liver disease. Am J Med 1958; 24: 358-67.

31 Kontos HA, Shapiro W, Mauck H, Patterson JL. General and regional alterations in cirrhosis of the liver. Am J Med 1963; 37: 526-35.

32 Siegel JH, Goldwyn RM, Farrell E, Gallin P, Friedman HP. Hyperdynamic states and the physiological determinants of survival in patients with cirrhosis and portal hypertension. Arch Surg 1974; 108: 282-92.

33 Lenz K, Hörtnagl H, Magometschnigg D, Kleinberger G, Druml W, Laggner A. Function of the autonomic nervous system in patients with hepatic encephalopathy. Hepatology 1985; 5: 831-6.

34 Bell-Reuss E, Trevino DL, Gottschalk C. Effect of renal sympathetic nerve stimulation on proximal water and sodium reabsorption. J Clin Invest 1976; 57: 1104-7.

35 Prosnitz EH, DiBona GF. Effect of decreased renal sympathetic nerve activity on renal tubular sodium reabsorption. Am J Physiol 1978; 235: 557-63.

36 Johnson MD, Berger AC. Circulating catecholamines in control of renal electrolyte and water excretion. Am J Physiol 1981; 240: 192-9.

37 Solis-Herruzo JA, Duran A, Favela V, et al. Effects of lumbar sympathetic block on kidney function in 
cirrhotic patients with hepatorenal syndrome. J Hepatol 1987; 5: 167-73.

38 Shapiro MD, Nichols KM, Groves BM, et al. Interrelationship between cardiac output and vascular resistance as determinants of effective arterial blood volume in cirrhotic patients. Kidney Int 1985; 28: 206-11.

39 Saruta T, Toyohisa E, Saito I. Angiotensin antagonists in liver disease. In: Epstein M, ed. The kidney in liver disease. New York: Elsevier, 1983: 441-50.

40 Levy M. Sodium retention and ascites formation in dogs with experimental cirrhosis. Am J Physiol 1977; 233: 572-85.

41 Levy M, Allotey JBK. Temporal relationships between urinary salt retention and altered system haemodynamics in dogs with experimental cirrhosis. $J$ Lab Clin Med 1978; 92: 560-9.

42 Gentilini P, Laffi G, Buzzelli G, et al. Functional renal alterations in chronic liver disease. Digestion 1980; 20: 73-8.

43 Lancestremere RG, Klingler EL, Frisch E, Papper S. Simultaneous determination of cardiac output and renal function in patients with Laennec's cirrhosis during the administration of the pressor amine, metaraminol. $J$ Lab Clin Med 1963; 61: 820-5.

44 Deen WM, Robertson CR, Brenner BM. Glomerular ultrafiltration. Fed Proc 1974; 33: 14-20.

45 Kew MC, Varma RR, Sampson DJ, Sherlock S. The effect of octapressin on renal and intrarenal blood flow in cirrhosis of the liver. Gut 1972; 13: 293-6.

46 Cohn JN, Tristani FE, Khatri IM. Systemic vasoconstrictor and renal vasodilator effects of PLV-2 (Octapressin) in man. Circulation 1968; 38: 151-7.

47 Gornel DL, Lancestremere RG, Papper S, Lowenstein LM. Acute changes in renal excretion of water and solute in patients with Laennec's cirrhosis, induced by the administration of the pressor amine, metaraminol. J Clin Invest 1962; 41: 594-603.

48 Fisher JE, Baldessarini RJ. False neurotransmitters and hepatic failure. Lancet 1971; ii: 75-9.

49 Barratt-Boyes BG, Wood EH. Cardiac output and related measurements and pressure values in the right heart and associated vessels, together with the response to the inhalation of high oxygen mixtures in healthy subjects. J Lab Clin Med 1958; 51: 72-90. 